\title{
PENGARUH PENGGUNAAN MEDIA POSTER DALAM MENULIS KARANGAN NARASI TERHADAP HASIL BELAJAR SISWA PADA MATA PELAJARAN BAHASA INDONESIA KELAS V SD NEGERI 77 KANAENG KABUPATEN TAKALAR
}

\author{
Hildayanti, Andi Sukri Samsuri, Tarman A Arief. \\ Pendidikan Guru Sekolah Dasar, Fakultas Keguruan dan Ilmu Pendidikan \\ Universitas Muhammadiyah Makassar \\ Iqramsyar34@gmail.com
}

\begin{abstract}
ABSTRAK
Penelitian ini menggunakan metode eksperimen, desain penelitian jenis one group pre test posttest design yaitu sebuah eksperimen yang dalam pelaksanaannya hanya melibatkan satu kelas sebagai kelas eksperimen. Tujuan penelitian ini adalah untuk mengetahui Pengaruh Penggunaan Media Poster dalam Menulis Karangan Narasi terhadap Hasil Belajar Siswa pada Mata Pelajaran Bahasa Indonesia Kelas V SD Negeri 77 Kanaeng Kabupaten Takalar tahun ajaran 2016/2017. Satuan eksperimen dalam penelitian ini adalah siswa kelas V sebanyak 20 orang. Penelitian dilaksanakan selama 8 kali pertemuan. Hasil analisis statistik inferensial menggunakan rumus uji $t$, diketahui bahwa nilai t Hitung yang diperoleh adalah 10.80 dengan frekuensi $d b=20-1=19$, pada taraf signifikan $=0,05$ diperoleh $\mathrm{t}$ Tabel $=2.093 \mathrm{Jadi}$, $\mathrm{t}$ Hitung $>\mathrm{t}$ Tabel atau Hipotesis nol (H0) ditolak dan Hipotesis alternative (H1) diterima. Hal ini membuktikan bahwa penggunaan media poster dalam menulis karangan pada pembelajaran bahasa Indonesia mempunyai pengaruh dari pada sebelum menggunakan media poster.
\end{abstract}

Kata kunci: media poster, menulis karangan narasi. 


\section{PENDAHULUAN}

Pendidikan dasar atau sekolah dasar merupakan momentum awal bagi anak untuk meningkatkan kemampuan dirinya. Dari bangku sekolah dasarlah mereka mendapatkan imunitas belajar yang kemudian menjadi kebiasaankebiasaan yang akan mereka lakukan dikemudian hari. Sehingga peran seorang guru sangatlah penting untuk dapat menanamkan kebiasaan baik bagi siswanya, bagaimana mereka dituntut memiliki kompetensi-kompetensi yang dapat meningkatkan kemampuan siswanya.

Salah satu keterampilan yang diharapakan dimiliki oleh siswa dari sekolah dasar ini adalah keterampilan berbahasa yang baik. Pembelajaran bahasa Indonesia di sekolah dasar diarahkan untuk meningkatkan kemampuan siswa berkomunikasi baik secara lisan maupun tulisan. Pembelajaran bahasa diarahkan untuk meningkatkan kemampuan peserta didik untuk berkomunikasi dalam bahasa Indonesia dengan baik dan benar baik secara lisan maupun tulis. Pembelajaran bahasa Indonesia, terutama di sekolah dasar tidak akan terlepas dari empat keterampilan berbahasa. Ada empat keterampilan berbahasa yaitu menyimak, berbicara, membaca dan menulis.

\section{Keterampilan} berbahasa khususnya menulis dapat dituangkan melalui tulisan. Menulis merupakan sebuah kegiatan yang bersifat produktif yaitu menghasilkan tulisan atau karangan. Menurut Dalman (2014: 4) Menulis merupakan sebuah proses kreatif menuangkan gagasan dalam bentuk bahasa tulis. Kegiatan menulis melibatkan aspek penggunaan tanda baca dan ejaan, penggunaan diksi dan kosa kata, penataan kalimat, pengembangan paragraf, pengelolaan gagasan, serta pengembangan model karangan. Dengan kata lain, dapat dinyatakan bahwa kegiatan menulis melibatkan aspek bahasa dan isi.

Keterampilan menulis salah satunya adalah menulis karangan. Menulis karangan merupakan kegiatan yang membutuhkan pengetahuan dan penalaran yang baik. Mengarang memerlukan pengetahuan dan penalaran yang logis. Mengarang pada hakikatnya adalah mengungkapkan atau menyampaikan gagasan dengan menggunakan bahasa tulis. Mengarang adalah kegiatan untuk mengungkapkan gagasan, ide, dan perasaan yang dituangkan dalam bahasa tulis yang disusun secara teratur dan sistematis 
sehingga memudahkan pembaca memahami isi pesan yang ingin disampaikan oleh penulis.

Keterampilan menulis karangan terdapat di kelas V semester II. Kegiatan mengarang pada dasarnya diawali dengan menentukan topik. Salah satu keberhasilan mengarang yaitu adanya kesesuaian antara topik dan tema, karena menulis karangan tidak terlepas dari suatu topik. Dalam menulis karangan siswa diajarkan untuk menyusun kerangka karangan kemudian menyusun kalimat yang benar dan mempen rhatikan kata serta meperhatikan ejaan yang tepat agar mudah dipahami oleh setiap pembaca.

Kegiatan terpenting dalam menulis karangan adalah dengan menentukan topik. Berdasarkan hasil observasi dan wawancara dengan guru kelas V SD Negeri 77 Kanaeng Kabupaten Takalar, peneliti menemukan sebuah fakta bahwa kemampuan siswa dalam menulis karangan masih tergolong rendah. Rendahnya kemampuan siswa dalam menulis karangan dikarenakan siswa masih kesulitan menentukan topik lalu menuangkan ide dan gagasan kedalam tulisan sehingga siswa membutuhkan waktu yang cukup lama untuk menulis karangan. Sebagian besar siswa masih kesulitan dalam penggunaan ejaan, huruf kapital dan tanda titik. Hal ini dikarenakan kurang tepatnya strategi yang digunakan guru dalam pembelajaran sehingga, siswa kesulitan dalam menuangkan potensi dan kreativitas dalam membuat karangan. Penggunaan metode pembelajaran yang kurang kreatif, guru masih menggunakan metode konvensional yaitu metode ceramah, penyampaian materi yang kurang memotivasi dan meningkatkan kreativitas siswa.

Rendahnya kemampuan siswa dalam menulis dikarenakan media yang digunakan dalam pembelajaran kurang bervariasi, hal ini dapat mempengaruhi kurangnya minat siswa dalam menulis. Media merupakan salah satu alat bantu untuk memudahkan siswa memahami materi pembelajaran. Salah satu media yang dapat digunakan untuk membantu siswa dalam menulis adalah dengan menggunakan media poster.

Penggunaan media poster diharapkan mampu meningkatkan minat dan kemampuan siswa dalam pembelajaran menulis, karena poster dapat menonjolkan kekuatan pesan, visual, dan warna. Menurut Anitah (2011: 26) poster adalah media visual yang memberikan informasi tentang ide atau gagasan yang mengajak seseorang 
baik secara individu maupun kelompok untuk mengikuti atau melaksanakan gagasan tersebut. Poster merupakan gabungan dari gambar dan tulisan ringkas dalam suatu bidang gambar yang memiliki nilai - nilai estetis agar dapat menarik perhatian orang yang melihat.

Berdasarkan uraian di atas, adapun rumusan masalah dalam penelitian ini adalah Apakah ada Pengaruh Penggunaan Media Poster dalam Menulis Karangan Narasi terhadap Hasil Belajar Siswa pada Mata Pelajaran Bahasa Indonesia Kelas V SD Negeri 77 Kanaeng Kabupaten Takalar?. Untuk mengetahui pengaruh penggunaan Media Poster dalam Menulis Karangan Narasi terhadap Hasil Belajar Siswa pada Mata Pelajaran Bahasa Indonesia Kelas V SD Negeri 77 Kanaeng Kabupaten Takalar?

\section{Pengertian Media Pembelajaran}

Dalam proses belajar mengajar, media yang digunakan untuk memperlancar komunikasi tersebut dinamakan media pembelajaran. Adapun menurut Sadiman (2008: 7) media pembelajaran adalah segala sesuatu yang dapat digunakan untuk menyalurkan pesan dari pengirim ke penerima sehingga dapat merangsang pikiran, perasaan, perhatian, dan minat serta perhatian siswa sedemikian rupa sehingga proses belajar terjadi.

Dengan demikian, jelaslah bahwa media pembelajaran adalah alat bantu yang digunakan dalam proses pembelajaran yang dimaksudkan untuk memudahkan, memperlancar komunikasi antara guru dan siswa sehingga proses pembelajaran berlangsung efektif dan berhasil dengan baik. Media pembelajaran menempati posisi yang cukup penting sebagai salah satu komponen dalam sistem pembelajaran. Tanpa media, komunikasi juga tidak akan terjadi dalam proses pembelajaran dan proses komunikasi juga tidak akan bisa berlangsung secara optimal.

\section{Media Poster}

Poster merupakan media grafis perpaduan antara gambar dengan tulisan untuk menyampaikan informasi, saran, seruan, peringatan, dan ide-ide lain. Menurut Anitah (2011: 25) menyatakan bahwa Poster merupakan gabungan dari gambar dan tulisan ringkas dalam suatu bidang gambar yang memiliki nilai - nilai estetis agar dapat menarik perhatian orang yang melihat. Poster merupakan gambar yang besar, yang memberi tekanan pada satu ide atau dua ide pokok, sehingga dapat dimengerti dengan melihat 
sepintas lalu. Poster tidak hanya penting untuk menyampaikan kesankesan tertentu, tapi dia mampu pula untuk mempengaruhi dan memotivasi tingkah laku orang yang melihatnya.

Poster yang baik adalah poster yang segera dapat menangkap pandangan orang dan menanamkan kepadanya pesan yang terkandung dalam poster itu. Pesan yang disampaikan harus jenis sepintas lalu, atau dapat menarik perhatian orang lewat untuk berhenti sebentar mengamatinya. Kalau tidak demikian poster itu tidak ada faedahnya. Poster tidak boleh ramai oleh detail, sehingga pesan yang akan disampaikan akan tenggelam dalam detail yang banyak itu. Gambar tidak saja harus besar, jelas dan menarik, akan tetapi harus sesuai dengan subjek yang divisualisasikan.

Poster dapat memberikan pengalaman kreatif, melalui poster pembelajaran siswa dapat lebih kreatif dan pembelajaran lebih baik sehingga pembelajaran tidak terkesan klsikal dan monoton. Melalui poster siswa dapat ditugaskan untuk membuat ide, cerita, karangan dari sebuah poster yang dapat dipajang. Diskusi kelas akan lebih hidup manakala guru menggunakan alat bantu poster sebagai bahan diskusi.

\section{Menulis}

Menulis merupakan sebuah kegiatan yang bersifat produktif yaitu menghasilkan tulisan atau karangan. Menurut Dalman (2014: 4) menulis merupakan sebuah proses kreatif menuangkan gagasan dalam bentuk bahasa tulis. Kegitan menulis melibatkan aspek penggunaan tanda baca dan ejaan, penggunaan diksi dan kosa kata, penataan kalimat, pengembangan paragraf, pengelolaan gagasan, serta pengembangan model karangan. Dengan kata lain, dapat dinyatakan bahwa kegiatan menulis melibatkan aspek bahasa dan isi.

Menulis sebagai keterampilan seseorang (individu) mengkomunikasikan pesan dalam sebuah tulisan. Keterampilan ini berkaitan dengan kegiatan seseorang dalam memilih, memilah, dan menyusun pesan untuk untuk ditransaksikan melalui bahasa tulis. Pesan yang ditransaksikan itu berupa ide (gagasan), kemampuan, keinginan, perasaan, atau informasi. Selanjutnya, pesan tersebut dapat menjadi isi sebuah tulisan yang ditransaksikan kepada pembaca.

Selain itu menulis juga dapat diartikan sebagai kemampuan menggunakan bahasa untuk menyatakan ide, pikiran atau perasaan 
kepada orang lain dengan menggunakan bahasa tulis. Menulis juga merupakaan aktifitas pengekspresian ide, gagasan, pikiran, atau perasaan ke dalam lambang-lambang kebahasaan. Semua aspek inilah yang diukur dalam tes kemampuan menulis. Dari konsep menulis ini dapat dikemukakan bahwa tes menulis merupakan tes kebahasaan yang mengukur kemamampuan menggunakan bahasa tulis untuk menyatakan ide, pikiran, atau perasaan.

\section{Karangan Narasi}

Karangan narasi berasal dari kata narration berarti bercerita adalah suatu bentuk tulisan yang berusaha menciptakan, menisahkan, dan merangkaikan tindak tanduk perbuatan manusia dalam sebuah peristiwa secara kronologis atau berlangsung dalam satu kesatuan waktu. Menurut Dalman (2014: 146) karangan narasi adalah cerita yang berusaha menciptakan, mengisahkan, dan merangkaikan tindak tanduk manusia dalam sebuah peristiwa yang terjadi dalam satu kesatuan waktu.

Berdasarkan pendapat diatas dapat disimpulkan bahwa karangan narasi adalah karangan yang menceritakan suatu kegiatan atau tindak tanduk manusia secara sistematis yang disertai oleh waktu.

\section{Hasil Belajar}

Secara sederhana yang dimaksud dengan hasil belajar siswa adalah kemampuan yang diperoleh anak setelah melalui kegiatan belajar. Karena belajar itu sendiri merupakan suatu proses dari seseorang yang berusaha untuk memperoleh suatu bentuk perubahan perilaku yang relatif menetap. Dalam kegiatan pembelajaran atau kegiatan intruksional, biasanya guru menetapkan tujuan pembelajaran. Dari sisi siswa, hasil belajar merupakan tingkat perkembangan mental yang lebih baik bila dibandingkan pada saat sebelum belajar.

Kemudian Menurut Slameto (2003: 18) Menyatakan bahwa "Hasil belajar adalah kemampuan yang dimiliki siswa setelah ia menerima pengalaman belajarnya". Hasil belajar mempunyai peranan penting dalam proses pembelajaran. Proses penilaian terhadap hasil belajar dapat memberikan informasi kepada guru tentang kemajuan siswa dalam upaya mencapai tujuan-tujuan belajarnya melalui kegiatan belajar. Selanjutnya dari informasi tersebut guru dapat menyusun dan membina kegiatankegiatan siswa lebih lanjut, baik untuk keseluruhan kelas maupun individu. 
Kingsley (Sudjana, 2005: 15) "membagi 3 macam hasil belajar yakni: (a) Keterampilan dan kebiasaan, (b) Pengetahuan dan pengertian dan, (c) Sikap dan cita-cita". Pendapat dari Horward Kingsley ini menunjukkan hasil perubahan dari semua proses belajar. Hasil belajar ini akan melekat terus pada diri siswa karena sudah menjadi bagian dalam kehidupan siswa tersebut.

\section{METODE PENELITIAN}

Jenis penelitian ini adalah penelitian eksperimen, yang melibatkan satu kelas sebagai kelas eksperimen. ). Dengan tujuan untuk mengetahui pengaruh penggunaan media poster dalam menulis karangan narasi terhadap hasil belajar siswa pada mata pelajaran bahasa Indonesia kelas V SD Negeri 77 Kanaeng Kabupaten Takalar. Desain penelitian ini merupakan penelitian preeksperimental designs jenis One-Group Pretest-Posttest Design. Dalam penelitian ini hasil perlakuan dapat diketahui lebih akurat, karena dapat membandingkan dengan keadaan sebelum diberi perlakuan (treatment).

Populasi dalam penelitian ini adalah seluruh siswa kelas V SD Negeri 77 Kanaeng Kabupaten Takalar tahun ajaran 2016/2017 sebanyak 20 orang.
Laki-laki 7 orang dan perempuan 13 orang,. . Sampel dalam penelitian ini adalah siswa kelas V SD Negeri 77 Kanaeng Kabupaten Takalar tahun ajaran 2016/2017 sebanyak 20 orang. Laki-laki 7 orang dan perempuan 13 orang, teknik pengambilan sampel yaitu dengan cara Total Sampling. Adapun instrumen yang digunakan dalam penelitian ini adalah lembar test. Teknik tes dalam penelitian ini adalah melakukan tes hasil belajar sebanyak dua kali, yaitu sebelum diberikan perlakuan (pre-test) dan setelah diberikan perlakuan (post-tes). Untuk menganalisi data yang diperoleh dari hasil penelitian akan digunakan analisis statistic deskriptif dan inferensial.

\section{HASIL DAN PEMBAHASAN}

Deskriptif Hasil Keterampilan Menulis Karangan Siswa Kelas V SD Negeri 77 Kanaeng Kabupaten Takalar sebelum dan sesudah Diberi Perlakuan Menggunakan Media Poster

Nilai statistik deskriptif pretest dan posttest murid yang diajarkan sebelum dan sesudah diberi perlakuan menggunakan media poster dapat dilihat pada paparan data hasil penelitian yang diperoleh. Data hasil observasi keterampilan menulis murid diperoleh berdasarkan hasil pretest yang dilaksanakan pada tanggal 27 Maret 2017 dan Posttest pada tanggal 07 April 2017 terhadap 20 siswa kelas V SD Negeri 77 
Kanaeng Kabupaten Takalar. Nilai statistik deskriptif dan tabel distribusi frekuensi dan persentase dapat dilihat pada Tabel berikut

Tabel 1 Rekapitulasi Hasil Kemampuan Menulis Karangan Siswa Kelas V SD Negeri 77 Kanaeng Sebelum Perlakuan (Pretest) dan Setelah Perlakuan (Posttest)

\begin{tabular}{|c|c|c|}
\hline \multirow{2}{*}{$\begin{array}{c}\text { Statistik } \\
\text { Deskriptif }\end{array}$} & \multicolumn{2}{|c|}{ Nilai } \\
\cline { 2 - 3 } & Pretest & Posttest \\
\hline Mean & 68,5 & 82,5 \\
\hline Median & 70 & 85 \\
\hline Modus & 70 & 85 \\
\hline Range & 50 & 40 \\
\hline Minimum & 35 & 55 \\
\hline Maximum & 85 & 95 \\
\hline Sum & 378.5 & 442,5 \\
\hline
\end{tabular}

Berdasarkan hasil analisis data statistik deskriptif pada tabel 4.1 di atas, memberi gambaran umum pretest sebelum perlakuan dengan menggunakan media poster yaitu memperoleh nilai rata-rata sebesar 68.5 dan setelah diberikan perlakuan dengan menggunakan media poster diperoleh nilai rata-rata sebesar 82.5. Dari nilai rata-rata tersebut dapat dilihat bahwa nilai rata-rata posttest untuk lebih tinggi daripada pretest.

Untuk mencari mean (ratarata) nilai pre-test dari murid kelas V SD Negeri 77 Kanaeng Kabupaten Takalar dapat dilihat melalui tabel di bawah ini :
Tabel 2. Perhitungan untuk mencari mean ( rata - rata) nilai pretest.

\begin{tabular}{|c|c|c|}
\hline $\mathbf{X}$ & $\mathbf{F}$ & F.X \\
\hline 35 & 1 & 35 \\
\hline 45 & 1 & 45 \\
\hline 55 & 1 & 55 \\
\hline 60 & 3 & 180 \\
\hline 65 & 1 & 65 \\
\hline 70 & 5 & 350 \\
\hline 75 & 4 & 300 \\
\hline $\mathbf{8 5}$ & 4 & 340 \\
\hline Jumlah & 20 & 1370 \\
\hline
\end{tabular}

Tabel 3 analisis pretest dan posttest.

\begin{tabular}{|c|c|c|c|c|}
\hline No & $\begin{array}{c}\mathrm{X} 1 \\
(\text { Pre- } \\
\text { test) }\end{array}$ & $\begin{array}{l}\mathrm{X} 2 \\
\text { (Post- } \\
\text { test) }\end{array}$ & $\begin{array}{l}\mathrm{d}= \\
\mathrm{X} 2 \\
- \\
\mathrm{X1}\end{array}$ & $\mathbf{d}^{2}$ \\
\hline 1 & 70 & 90 & 20 & 400 \\
\hline 2 & 55 & 75 & 20 & 400 \\
\hline 3 & 70 & 85 & 15 & 225 \\
\hline 4 & 85 & 95 & 10 & 100 \\
\hline 5 & 75 & 95 & 20 & 400 \\
\hline 6 & 80 & 85 & 5 & 25 \\
\hline 7 & 85 & 95 & 10 & 100 \\
\hline 8 & 60 & 75 & 15 & 225 \\
\hline 9 & 75 & 90 & 15 & 225 \\
\hline 10 & 60 & 75 & 15 & 225 \\
\hline 11 & 60 & 85 & 25 & 625 \\
\hline 12 & 70 & 75 & 5 & 25 \\
\hline 13 & 75 & 85 & 10 & 100 \\
\hline 14 & 45 & 55 & 10 & 100 \\
\hline 15 & 35 & 60 & 25 & 625 \\
\hline
\end{tabular}




\begin{tabular}{|c|c|c|c|c|}
\hline 16 & 65 & 85 & 20 & 400 \\
\hline 17 & 70 & 85 & 15 & 225 \\
\hline 18 & 70 & 80 & 10 & 100 \\
\hline 19 & 75 & 85 & 10 & 100 \\
\hline 20 & 85 & 95 & 10 & 100 \\
\hline & 1370 & 1650 & 285 & 4725 \\
\hline
\end{tabular}

Pengaruh Media Poster Terhadap Hasil Keterampilan Menulis Karangan Siswa Kelas V SD Negeri 77 Kanaeng Kabupaten Takalar

Berdasarkan

hipotesis

penelitian yakni "Apakah ada

Pengaruh Penggunaan Media Poster

dalam Menulis Karangan Narasi

terhadap Hasil Belajar Siswa pada

Mata Pelajaran Bahasa Indonesia

Kelas V SD Negeri 77 Kanaeng

Kabupaten Takalar", maka teknik yang digunakan untuk menguji hipotesis tersebut adalah teknik analisis statistik inferensial dengan menggunakan uji-t.

Langkah-langkah dalam pengujian hipotesis penelitian adalah sebagai berikut:

a. Mencari nilai "Md" dengan menggunakan rumus:

$$
\begin{aligned}
M d & =\frac{\sum d}{N} \\
& =\frac{285}{20}
\end{aligned}
$$

$\mathrm{Md}=14.25$

b. Mencari nilai " $\sum \mathrm{X}^{2} \mathrm{~d}$ " dengan menggunakan rumus:

$$
\begin{aligned}
\sum \mathrm{X}^{2} \mathrm{~d} & =\sum d^{2}-\frac{\left(\sum d\right)^{2}}{N} \\
& =4725-\frac{(285)^{2}}{20}
\end{aligned}
$$

c. Menentukan t- Hitung

$$
\begin{aligned}
& \mathrm{t}=\frac{M d}{\sqrt{\frac{5 x^{2} d}{N(N-1)}}} \\
& \mathrm{t}=\frac{14,25}{\sqrt{\frac{663_{,} 75}{20(20-1)}}} \\
& \mathrm{t}=\frac{14,25}{\sqrt{\frac{663_{r} 75}{380}}} \\
& \mathrm{t}=\frac{14,25}{\sqrt{1,75}} \\
& \mathrm{t}=\frac{14,25}{1,32} \\
& \mathrm{t}=10.80
\end{aligned}
$$

d. Menetukan nilai t Tabel

Untuk mencari $t$ Tabel peneliti menggunakan tabel distribusi $\mathrm{t}$ dengan taraf signifikan $a=0.05$ dan $\quad d . b=N-1=$ 20-1 =19 maka diperoleh $t_{0,05}=2.093$

Setelah diperoleh $t_{\text {Hitung }}=10.80$ dan $\mathrm{t}_{\text {Tabel }}=2.093$ maka diperoleh $\mathrm{t}_{\text {Hitung }}>\mathrm{t}_{\text {Tabel }}$ atau $10.80>2.093$. Sehingga dapat disimpulkan bahwa $\mathrm{H}_{0}$ ditolak dan $\mathrm{H}_{\mathrm{a}}$ diterima. Ini berarti bahwa penggunaan media poster dalam proses pembelajaran berpengaruh terhadap hasil keterampilan menulis karangan siswa kelas V SD Negeri 77 Kanaeng Kabupaten Takalar.

Penelitian yang bertujuan untuk mengetahui pengaruh media poster terhadap hasil keterampilan menulis karangan siswa kelas V SD Negeri 77 Kanaeng Kabupaten Takalar pada kompetensi dasar menulis, menulis 
karangan berdasarkan pengalaman dengan memperhatikan pilihan kata dan penggunaan ejaan.

Pemberian perlakuan dengan menggunakann media poster untuk mempermudah proses pembelajaran menulis karangan karena siswa akan termotifasi dalam berpikir karena penggunaan media yang tepat sesuai dengan materi pembelajaran.

Berdasarkan hasil penelitian yang telah diuraikan dalam analisis data, secara deskriptif hasil keterampilan menulis karangan siswa kelas V SD Negeri 77 kananeng Kabupaten Takalar yang mengikuti pembelajaran dengan menggunakan media poster berada dalam kategori sangat baik. Pernyataan ini diuraikan dari hasil analisis data, rata-rata hasil keterampilan menulis karangan yang mengikuti posttest adalah 82,5 yang terdapat pada interval 90-100 (sangat tinggi), sedangkan hasil keterampilan menulis karangan siswa kelas V SD Negeri 77 Kanaeng Kabupaten Takalar yang mengikuti pretest tanpa menggunakan media poster berada dalam kategori tinggi. Hal ini, karena rata-rata hasil pretest adalah 63,75 yang terdapat pada interval 80-89 (tinggi). Berdasarkan dari data tersebut menunjukkan bahwa hasil posttest lebih tinggi dari nilai pretest.

Keterampilan menulis karangan siswa apabila dibandingkan dari kedua hasil keterampilan menulis yang diperoleh sebelum dan sesudah penggunaan media poster, ternyata terdapat perbedaan yang cukup signifikan diantara keduanya, yakni sebelum menggunakan media poster dalam pembelajaran menulis karangan nilai siswa kelas V SD Negeri 77 Kanaeng Kabupaten Takalar yang mengikuti pembelajaran bahasa Indonesia, Tingkat hasil keterampilan menulis karangan siswa kelas V SD Negeri 77 Kanaeng Kabupaten Takalar pada pretest terdapat 4 siswa atau $20 \%$ berada pada kategori tinggi, 9 siswa atau $45 \%$ berada pada kategori sedang, 5 siswa atau $25 \%$ berada pada kategori rendah dan 2 siswa atau $10 \%$ berada pada kategori sangat rendah. Setelah diberikan perlakuan berupa penggunaan media poster sebanyak 3 kali pertemuan, maka tingkat hasil keterampilan menulis karangan siswa kelas V SD Negeri 77 Kanaeng Kabupaten Takalar berpengaruh, sebanyak 6 siswa atau 30\% siswa berada pada kategori sangat tinggi yang sebelumnya tidak ada siswa yang masuk kategori sangat tinggi, 8 siswa atau $40 \%$ siswa berada pada kategori tinggi, 4 siswa atau $20 \%$ berada pada kategori sedang, 2 siswa atau $10 \%$ berada pada kategori rendah dan tidak ada siswa berada pada kategori sangat rendah.

Media Poster adalah sebuah media yang menonjolkan kesan visual dan warna sehingga jika digunakan dalam pembelajaran menulis karangan akan sangat efektif karena siswa akan mudah untuk termotivasi dalam berfikir.

Hasil analisis data secara inferensial, memperlihatkan adanya pengaruh 
penggunaan media poster terhadap hasil keterampilan menulis murid. Hal ini dapat dilihat dari hasil perhitungan dengan menggunakan analisis uji-t. dari hasil analisis diperoleh $t_{\text {Hitung }}=10.80$ dan $t_{\text {Tabel }}=$ 2.093 maka diperoleh $t_{\text {Hitung }}>t_{\text {Tabel }}$ atau $10.80>2.093$. Sehingga dapat disimpulkan bahwa $\mathrm{H}_{0}$ ditolak dan $\mathrm{H}_{\mathrm{a}}$ diterima. Ini berarti bahwa penggunaan media poster dalam proses pembelajaran berpengaruh terhadap hasil keterampilan menulis karangan siswa kelas V SD Negeri 77 Kanaeng Kabupaten Takalar.

Sejalan dengan Anitah (2011: 25) menyatakan bahwa "Poster merupakan gabungan dari gambar dan tulisan ringkas dalam suatu bidang gambar yang memiliki nilai - nilai estetis agar dapat menarik perhatian orang yang melihat. Poster tidak hanya penting untuk menyampaikan kesankesan tertentu, tapi dia mampu pula untuk mempengaruhi dan memotivasi tingkah laku orang yang melihatnya."

Berdasarkan uraian tersebut dapat disimpulkan bahwa media poster dapat mempengaruhi keterampilan menulis karangan siswa kelas V SD Negeri 77 Kananeg Kabupaten Takalar, dalam arti murid yang diajar dengan menggunakan media poster pada pembelajaran menulis karangan memperlihatkan hasil yang lebih tinggi. Sehingga dapat dikatakan pembelajaran menulis karangan dengan menggunakan media poster lebih berhasil dibandingkan dengan pembelajaran tanpa media poster atau dapat disebut pembelajaran konvensional, hal ini dikarenakan media poster adalah media pembelajaran yang paling efektif untuk memotifasi siswa dalam menulis karangan.

\section{KESIMPULAN}

Berdasarkan hasil penelitian, analisis data dan pembahasan, maka dapat disimpulkan bahwa Hasil keterampilan menulis karangan siswa sebelum menggunakan media poster memperoleh nilai rata-rata sebesar 68,5 dengan nilai tertinggi 85 dan nilai terendah 35 pada pretest, terdapat 4 siswa atau $20 \%$ berada pada kategori tinggi, 9 siswa atau 45\% berada pada kategori sedang dan 5 siswa atau 25\% berada pada kategori rendah, terdapat 2 siswa atau $10 \%$ berada pada kategori sangat rendah. Hasil keterampilan menulis karangan setelah diberikan perlakuan berupa penggunaan media poster sebanyak 3 kali pertemuan, nilai rata-rata sebesar 82,5 sebanyak 6 siswa atau 30\% siswa berada pada kategori sangat tinggi yang sebelumnya tidak ada siswa yang masuk kategori sangat tinggi, 8 siswa atau 40\% siswa berada pada kategori tinggi, 4 siswa atau $20 \%$ berada pada kategori sedang, 2 siswa atau $10 \%$ berada pada kategori rendah dan tidak ada siswa berada pada kategori sangat rendah. Ada pengaruh penggunaan media poster terhadap keterampilan menulis karangan narasi siswa kelas V SD Negeri 77 Kanaeng Kabupaten Takalar. 
Sehubungan dengan kesimpulan hasil penelitian di atas, maka saran yang dapat dikemukakan oleh peneliti adalah: (1) Dengan hasil penelitian ini maka disarankan pada guru dan pihak sekolah agar dapat menggunakan media poster dalam pembelajaran menulis dan menambah dengan menggunakan media dan model pembelajaran yang bervariasi yang dapat menjadikan murid semakin termotivasi untuk belajar. (2) Penggunaan media poster membantu memudahkan belajar bagi murid dan juga memudahkan pengajaran bagi guru dan memberikan pengalaman lebih banyak kepada murid dalam proses pembelajaran maupun di luar proses pembelajaran.

\section{DAFTAR PUSTAKA}

Anitah, Sri. 2011. Strategi Pembelajaran di Sekolah Dasar. Jakarta: Universitas Terbuka.

Dalman. 2014. Keterampilan Menulis. Jakarta: Raja Grafindo Persada.

Hasbullah. 2009. Dasar-dasar Ilmu Pendidikan. Jakarta: PT Grafindo Persada.

Puspitasari. 2011. Penggunaan Media Poster untuk Meningkatkan Keterampilan Menulis Puisi Siswa Kelas V SDN Sumbersari. Malang: Universitas Negeri Malang

Risqi, Ahmad. 2015. Upaya Peningkatan Hasil Belajar Bahasa Indonesia dengan Menggunakan media Poster pada Peserta Didik Kelas
III SD Negeri 1 Kaladan Jaya. Palangkaraya: Universitas Muhammadiyah Palangka Raya.

Sadiman, Arief. 2008. Media Pendidikan. Jakarta: CV Rajawali dan Pustekkom Dikbud.

Susanto, Ahmad. 2013. Teori Belajar dan Pembelajaran di Sekolah Dasar. Jakarta: Kencana Pramedia Grup.

Sudjana, N. 2005. Penilaian Hasil Proses Belajar Mengajar. Bandung: PT Remaja Rosdikarya.

Sumanto. 2014. Teori dan Aplikasi Metode Penelitian. Jakarta: PT Buku Seru.

Slameto. 2003. Belajar dan Faktor yang Mempengaruhinya. Jakarta: PT Rhineka Cipta.

Sisdiknas. 2006. Himpunan Peraturan Perundang-Undangan UU No. 20 Tahun 2003. Jakarta: Fokus Media

Vadri, Kalapati. 2013. Kemampuan Menulis Karangan Persuasif Melalui Media Poster pada Siswa Kelas X Sekolah Menengah Kejuruan Negeri 4 Tandjungpinang

Tandjungpinang: Universitas Maritim Raja Ali Haji.

Wasliman, I. 2007. Problematika Pendidikan Dasar. Bandung: SpsUpi

Wakhyu. 2013. Penggunaan Media Poster untuk Meningkatkan Aktivitas dan Hasil Belajar Bahasa Indonesia pada Peserta Didik Kelas VI. Lampung: Universitas Lampung 